\title{
Mechanism of Vitamin $B_{12}$ Uptake by Erythrocytes *
}

\author{
François P. Retief, $\dagger$ Chester W. Gottlieb, and Victor Herbert $\ddagger$ \\ (From the Department of Hematology, The Mount Sinai Hospital, New York, N. Y.)
}

Pitney, Beard, and Van Loon (2) and Ostrowski, Skarzynski, and Zak (3) reported in 1954 that vitamin $\mathrm{B}_{12}$ is bound primarily to $\alpha$-globulin in normal serum. Pitney and his colleagues (2) also noted that $\beta$-globulin can bind $\mathrm{B}_{12}$ added in vitro, but they considered this as "free $\mathrm{B}_{12}$ " because, unlike $\mathrm{B}_{12}$ bound to $\alpha$-globulin, Euglena gracilis is able to utilize it without prior heat treatment. Miller (4) showed that $\mathrm{B}_{12}$ added to serum in vitro binds predominantly to $\alpha_{2^{-}}$and $\beta$-globulin and that this fraction is nondialyzable. Hall and Finkler (5) confirmed the presence of two main $\mathrm{B}_{12}$-binding globulins in serum, which Miller and Sullivan (6) and Weinstein, Weissman, and Watkin (7) had shown to be constituents of the seromucoid fraction.

Little is known about the transfer of $B_{12}$ from plasma to tissues. Callender and Lajtha (8) reported that partial maturation of megaloblasts in vitro can be produced by cyanocobalamin only when gastric juice or serum is present, thus suggesting the importance of a transferring protein. Miller, Raney, and Hunter (9) and Herbert (10) demonstrated that hog intrinsic factor promotes the uptake of $\mathrm{B}_{12}$ by rat liver slices; human serum has a similar effect (11). Cooper and Paranchych (12) found mouse Ehrlich ascites tumor cells and HeLa cells able to absorb $B_{12}$ only in the presence

\footnotetext{
* Submitted for publication February 28, 1966; accepted September 6, 1966.

This study was supported in part by grants AM-09564 and AM-09062 from the National Institutes of Health, U. S. Public Health Service, and the Albert A. List, Frederick Machlin, and Anna Ruth Lowenberg Funds.

A preliminary report of part of this study has been published in abstract form (1).

† International postdoctoral research fellowship 1 F05TW-918-01 from the U. S. Public Health Service. Current address: Medical School, University of Stellenbosch, Bellville, South Africa.

$\ddagger$ Recipient of City of New York Health Research Council Career Scientist Award I-435.

Address requests for reprints to Dr. Victor Herbert, Mount Sinai Hospital, 100th St. and 5th Ave., New York, N. Y. 10029.
}

of human serum and ascites fluid; human gastric juice and hog intrinsic factor do not show such an effect. These workers subsequently suggested that the $\mathrm{B}_{12}$-binding fraction of ascites fluid may be a mucoprotein (13). Finkler, Hall, and Landau (14) reported that $B_{12}$ uptake by HeLa cells in tissue culture is specifically increased by the $B_{12}{ }^{-}$ binding $\beta$-globulin of human serum and that liver uptake of $\mathrm{B}_{12}$ from plasma seems to occur more rapidly when the vitamin is bound to $\beta$-globulin than when bound to $\alpha$-globulin (15).

We have studied cyanocobalamin transfer to tissues by investigating erythrocyte uptake of ${ }^{57} \mathrm{Co}-$

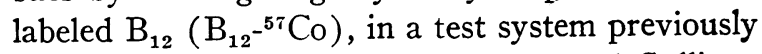
used by Herbert (16) and Herbert and Sullivan (17). It has been reported that mature erythrocytes do not take up significant amounts of $\mathrm{B}_{12}$ $(18,19)$, but uptake increases with a rising reticulocyte count (17).

\section{Methods}

\section{Materials}

Reticulocyte-rich blood was collected in heparinized Vacutainer ${ }^{1}$ tubes from patients with hemolytic disease or iron deficiency anemia responding to treatment. In all cases plasma $B_{12}$ levels were determined by coated charcoal assay (20). Initially the $\mathrm{ABO}$ and $\mathrm{Rh}$ blood types of test cells were determined to exclude possible agglutination reactions when serum was added to the test system. However, we found that blood group incompatibility between serum and cells did not cause agglutination under the conditions of the test, due presumably to the relatively high content of red cells. Reticulocyte counts were done by standard methods with brilliant cresyl blue stain.

Test cells were thrice washed with 2 vol physiological saline containing $10 \mathrm{mM}$ calcium chloride $\left(\mathrm{CaCl}_{2}-\mathrm{NaCl}\right)$. Washing with saline instead of $\mathrm{CaCl}_{2}-\mathrm{NaCl}$ was later shown not to affect results. Washed cells were finally suspended in equal volumes of $\mathrm{CaCl}_{2}-\mathrm{NaCl}$, and a microhematocrit was performed on each working suspension.

Normal blood with a reticulocyte count less than $1.5 \%$ was used as a control; cells were prepared and suspended as above.

\footnotetext{
${ }^{1}$ Purchased as Vacutainers (\#3208 KA), 20-ml capacity, from Becton Dickinson, Rutherford, N. J.
} 


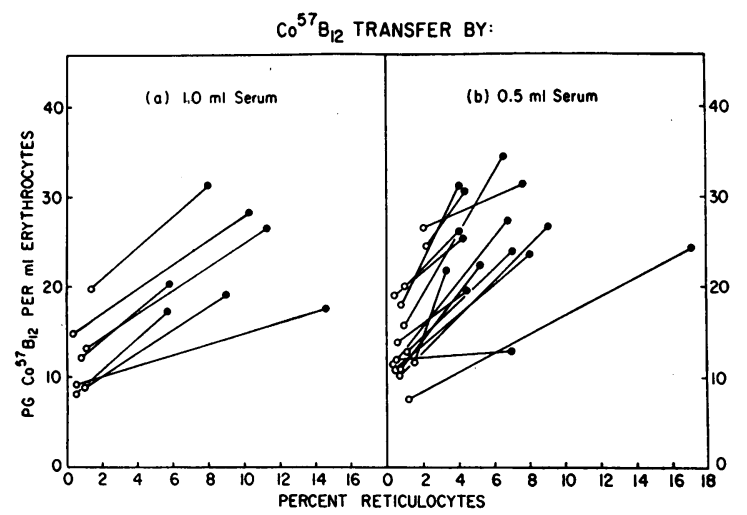

Fig. 1. Serum-Mediated $B_{12^{-5}}{ }^{57}$ Co UPtake by eRYthROCYTES. The increased amount (in picograms) of

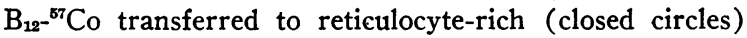
over reticulocyte-poor (open circles) suspensions of erythrocytes, in the same experiments, is shown by connected points.

Test serum was separated from blood allowed to clot in Vacutainer tubes. Pooled sera collected from normal subjects and from pregnant women were shown to give comparable results for the purpose of this study. In isolated instances heparinized plasma was used instead of serum; plasma and serum showed identical $B_{12}$ transfer to erythrocytes. In all cases serum $B_{12}$ level (20) and unsaturated vitamin $\mathrm{B}_{12}$ binding capacity $\left(\mathrm{UB}_{12} \mathrm{BC}\right)$ (21) were determined by coated charcoal assay.

$\mathrm{B}_{12}{ }^{57} \mathrm{Co}$ with specific activity of approximately $20 \mu \mathrm{c}$ per $\mu \mathrm{g}$ was used, diluted in saline to a working solution containing the desired concentration of the vitamin.

\section{Procedures}

A subsaturating dose of $\mathrm{B}_{12}{ }^{-57} \mathrm{Co}$ was added to $0.5 \mathrm{ml}$ or $1.0 \mathrm{ml}$ test serum in a $10-\mathrm{ml}$ test tube; no unbound radioactive $B_{12}$ would thus be present. One nanogram $\mathrm{B}_{12}{ }^{57} \mathrm{Co}$ ( $0.1 \mathrm{ml}$ of $10 \mathrm{ng}$ per $\mathrm{ml}$ solution) per $\mathrm{ml}$ serum was found to be a convenient amount for most test systems and yielded erythrocyte uptake of the order of $1 \%$ of the $\mathrm{B}_{12^{2}}{ }^{57} \mathrm{Co}$ added. The specimen was gently shaken and allowed to stand at room temperature for 15 minutes to ensure adequate binding of the vitamin to protein. Two $\mathrm{ml}$ of test cell suspension was then added and the mixture incubated for 1 hour in a water bath at $37^{\circ} \mathrm{C}$, with constant mechanical agitation. (In later experiments the incubation period was decreased to 30 minutes, since the results were almost identical with 1-hour incubation.) The cells in the incubation mixture were then thrice washed with $4 \mathrm{ml} \mathrm{CaCl}-\mathrm{NaCl}$ to remove free $\mathrm{B}_{12}{ }^{57} \mathrm{Co}$ (three such washes achieved a "base-line" level of ${ }^{57} \mathrm{Co}$ ) and subsequently hemolyzed with sufficient distilled water to bring the test volume to $3 \mathrm{ml}$. The radioactivity of the hemolyzed specimen was determined in a well-type scintillation counter and compared with a standard containing $1 \mathrm{ng} \mathrm{B}_{12}{ }^{\mathrm{b}} \mathrm{Co}$ in $3.0 \mathrm{ml}$ saline.
Experiments were performed in duplicate and accompanied by two controls: 1) test serum replaced by an equal volume of saline, and 2) reticulocyte-rich erythrocyte suspension replaced by a 2-ml suspension of erythrocytes with a normal reticulocyte count. Occasionally reticulocyte-rich and reticulocyte-poor suspensions were obtained from a single sample by differential centrifugation with $30 \%$ bovine albumin (22).

\section{Results}

$\mathrm{B}_{12}{ }^{-57} \mathrm{Co}$ uptake by erythrocytes varied from experiment to experiment even with the same reticulocyte count and test serum. For a given experiment with a single source of serum and reticulocytes, the uptake of $\mathrm{B}_{12^{-57} \mathrm{Co}}$ was quite constant; in three separate experiments the coefficient of variation was $5.4 \%$ (nine observations), $3.9 \%$ (four observations), and $3.3 \%$ (four observations). As indicated in Figure 1, serummediated $\mathrm{B}_{12}{ }^{-57} \mathrm{Co}$ uptake by reticulocyte-rich erythrocytes was consistently greater than by reticulocyte-poor erythrocytes, with a fairly constant uptake slope.

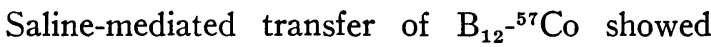
no significant reticulocyte dependence and was quantitatively less than serum-mediated transfer (Figure 2). Occasionally, relatively high salinemediated transfer occurred, which may have been due to small amounts of serum trapped in an inadequately washed test cell suspension.

Transfer of $\mathrm{B}_{12}{ }^{-57} \mathrm{Co}$ to erythrocytes appears to be governed both by extracellular factors in the

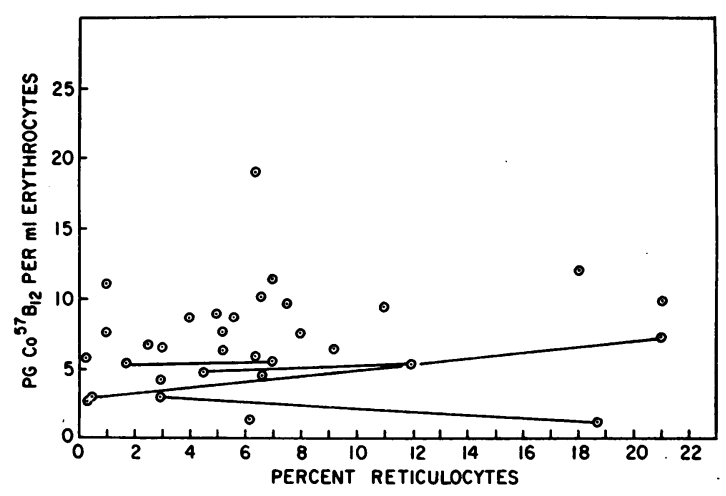

Fig. 2. Saline-Mediated $B_{12^{-}}{ }^{57}$ Co UPtake by eRYthroCYTES. The amount of $\mathrm{B}_{12}{ }^{57} \mathrm{Co}$ taken up by reticulocyterich suspensions of erythrocytes is less from saline than serum (compare with Figure 1). Where tested in the same experiment there was no difference in the uptake of $\mathrm{B}_{12}{ }^{-57} \mathrm{Co}$ by reticulocyte-rich as compared to reticulocytepoor suspensions of erythrocytes (connected points). 
transferring medium and cellular factors in the erythrocytes.

\section{Extracellular factors}

The rate of $B_{12}{ }^{-57}$ Co uptake by erythrocytes. A diluting volume of $3 \mathrm{ml}$ cold saline $\left(4^{\circ} \mathrm{C}\right)$ was added to incubating mixtures after incubation periods ranging from 2 to 60 minutes. Specimens were then immediately centrifuged and washed, and radioactivity of the hemolysate was counted.

In Figure 3 the uptake curve from normal serum is compared with that from saline. It is evident that at least three quarters of the total serummediated $\mathrm{B}_{12}$ transfer takes place during the first 5 minutes. Transfer is maximal at approximately 20 minutes. Uptake from saline is quantitatively much less and shows a slight progressive increase over 1 hour after an initial rapid uptake phase.

The role of ionic calcium, magnesium, and strontium in $B_{12}$ transfer. The effect on the test system of $0.5 \mathrm{ml} 0.1 \mathrm{M}$ Ca EDTA, $\mathrm{Mg}$ EDTA, $\mathrm{Sr}$ EDTA, and $\mathrm{Na}_{2}$ EDTA was determined (Table I). The finding that $\mathrm{Na}_{2}$ EDTA greatly diminished $B_{12}$ transfer whereas Ca EDTA and

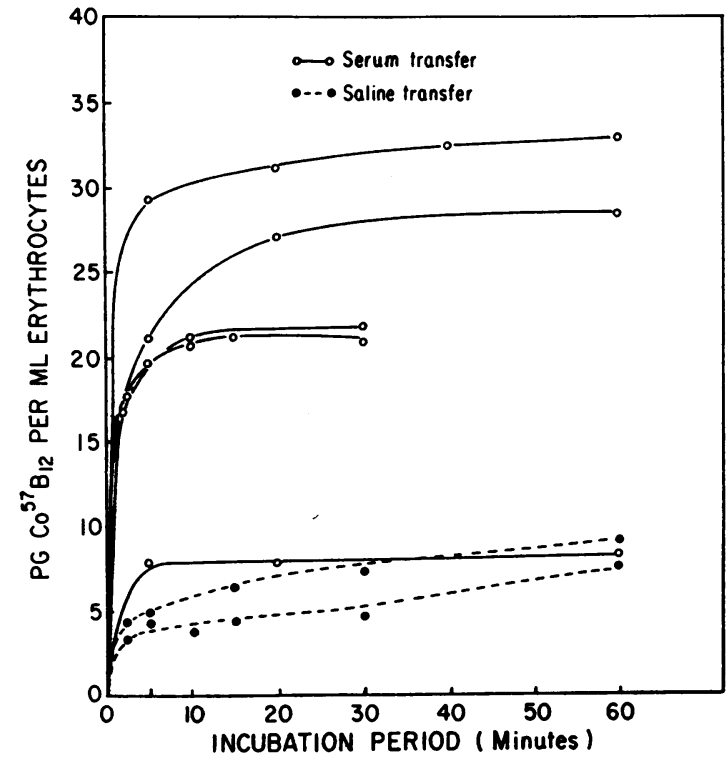

Fig. 3. EFFECT OF INCUBATION TIME ON THE UPTAKE OF $B_{12}{ }^{57}$ CO BY SUSPENSIONS WITH VARYING RETICULOCYTE count. Uptake from normal serum (four experiments) and saline (two experiments) is compared. Of the erythrocytes, $10 \%$ were reticulocytes in the highest serum and saline curve, $8 \%$ in the next highest serum and saline curve, $5 \%$ in the middle two serum curves, and $3 \%$ in the lowest serum curve.
TABLE I

Effect of Ca EDTA, Mg EDTA, Sr EDTA, and $\mathrm{Na}_{2}$ EDTA on $B_{12^{-57}}$ Co uptake by erythrocytes from serum and saline

\begin{tabular}{cc}
\hline \hline $\begin{array}{c}\text { EDTA (10-1 } \mathrm{M}, 0.5 \mathrm{ml}) \\
\text { added to } 0.5 \mathrm{ml} \\
\text { uptake medium }\end{array}$ & $\begin{array}{c}\text { B12-57Co up- } \\
\text { take by } 1 \mathrm{ml} \\
\text { erythrocytes as } \\
\text { \% of uptake } \\
\text { from control* }\end{array}$ \\
\hline A.† None (Control) & 100 \\
Ca EDTA & $97.6 \pm 1.8$ \\
$\mathrm{Mg}$ EDTA & $94.7 \pm 3.7$ \\
Sr EDTA & $68.6 \pm 2.1$ \\
$\mathrm{Na}$ EDTA & $18.0 \pm 0.8$ \\
B.† $\mathrm{None}_{2}$ (Control) & 100 \\
$\mathrm{Na}_{2}$ EDTA & $105.6 \pm 7.3$
\end{tabular}

* Mean \pm standard error of five determinations. † Serum used as uptake medium.

† Saline used as uptake medium.

Mg EDTA did not affect it significantly suggests that ionic calcium or magnesium is essential for the reaction. Strontium appears to partially replace these cations in this system.

When test cells were preincubated with $10^{-1} \mathrm{M}$ $\mathrm{Na}_{2}$ EDTA for 30 minutes, thrice washed with $10 \mathrm{mM} \mathrm{CaCl}{ }_{2}-\mathrm{NaCl}$, resuspended in this medium, and then used in the standard $\mathrm{B}_{12}{ }^{-57}$ Co transfer experiments, $\mathrm{B}_{12}{ }^{-57} \mathrm{Co}$ uptake was unimpaired. This showed that $\mathrm{Na}_{2}$ EDTA did not per se cause irreversible damage to red cells. The uptake of $1 \mathrm{ng}$ $\mathrm{B}_{12}{ }^{-57} \mathrm{Co}$ from $0.5 \mathrm{ml}$ saline was not decreased by the addition of $0.5 \mathrm{ml} \quad 10^{-1} \mathrm{M} \quad \mathrm{Na}_{2}$ EDTA (Table I).

The effect of $p H$ and temperature changes. On adjusting the $\mathrm{pH}$ of the test system with $\frac{1}{3} \mathrm{~N}$ sodium hydroxide and $\frac{1}{3} \mathrm{~N}$ hydrochloric acid and checking both initial $\mathrm{pH}$ and final $\mathrm{pH}$ at the end of the 1-hour incubation, we found maximal $\mathrm{B}_{12}{ }^{-57} \mathrm{Co}$ transfer to occur in the $\mathrm{pH}$ range 7.2 to 8.2. Outside this range hemolysis rendered experimental conditions progressively less reliable.

Incubation at $4^{\circ} \mathrm{C}, 23^{\circ} \mathrm{C}, 37^{\circ} \mathrm{C}$, and $45^{\circ} \mathrm{C}$, respectively, after the test system had been allowed to equilibrate at these temperatures for 15 minutes before addition of $\mathrm{B}_{12}{ }^{-57} \mathrm{Co}$, demonstrated that maximal $B_{12}$ transfer occurred at $37^{\circ} \mathrm{C}$, with progressive but moderate decrease in uptake at lower and higher temperatures (Figure 4).

The transfer of $B_{12^{3}}{ }^{37} \mathrm{Co}$. In Figure 5, the transfer of $\mathrm{B}_{12}{ }^{-57} \mathrm{Co}$ added to pernicious anemia serum [native $B_{12}, 37$ picograms (pg) per $\mathrm{ml}$; $\mathrm{UB}_{12} \mathrm{BC}, 1,728 \mathrm{pg}$ per ml] containing varying concentrations of the radioactive vitamin $(200 \mathrm{pg}$ 


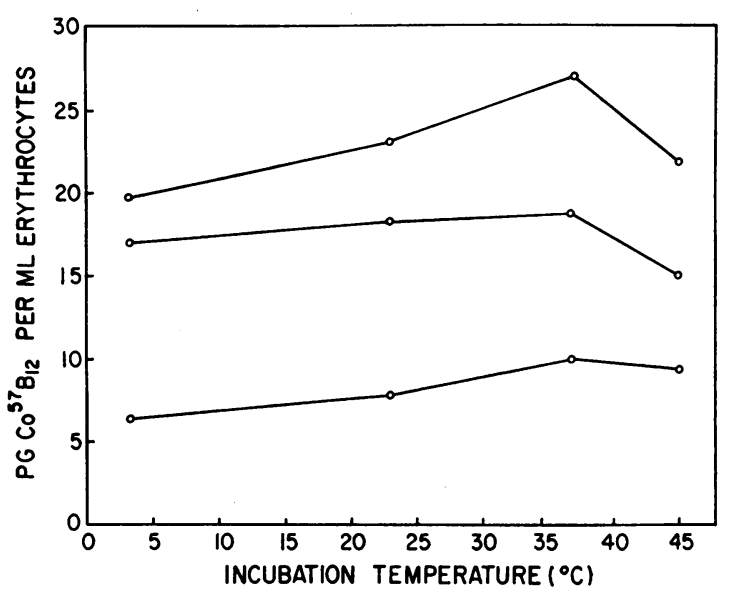

Fig. 4. EFFECT OF TEMPERATURE ON SERUM-MEDIATED $\mathrm{B}_{12^{-}}{ }^{57} \mathrm{CO}$ UPTAKE BY RETICULOCYTE-RICH ERYTHROCYTES. Results of three experiments, utilizing erythrocyte suspensions with different reticulocyte counts. Of the erythrocytes, $9 \%$ were reticulocytes in the top curve, $5 \%$ in the middle curve, and $4 \%$ in the bottom curve.

per $\mathrm{ml}, 600 \mathrm{pg}$ per $\mathrm{ml}$, and 1,000 pg per $\mathrm{ml}$ ) is presented so that transfer from the same total amounts of protein-bound $\mathrm{B}_{12}{ }^{-57} \mathrm{Co}$ can be directly compared. It is evident that radioactive $B_{12}$ is

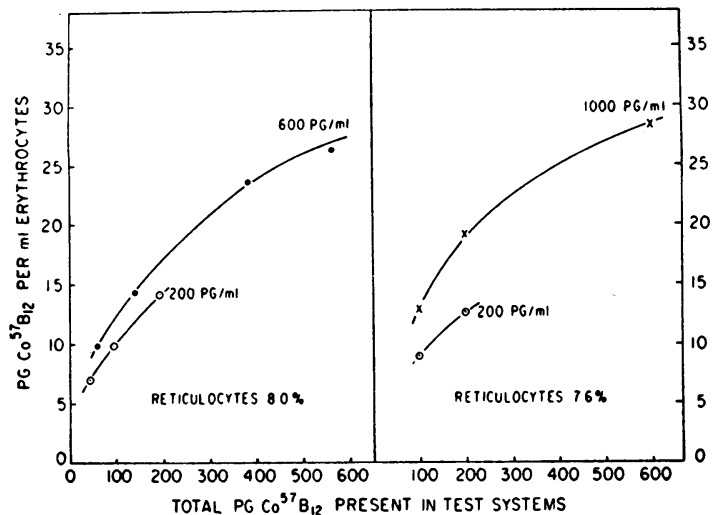

Fig. 5. EFFECt OF VARYing CONCENTRATIONS OF $\mathrm{B}_{12}{ }^{87} \mathrm{Co}$ LABELED PERNICIOUS ANEMIA SERUM ON THE TRANSFER OF THE RADIOACTIVE VITAMIN TO RETICULOCYTE-RICH ERYTHROCYTES. The pernicious anemia serum had an endogenous unsaturated $\mathrm{B}_{12}$ binding capacity of $1,728 \mathrm{pg}$ per $\mathrm{ml}$. $\mathrm{B}_{122^{-}}{ }^{57} \mathrm{Co}$ was added to portions of the pernicious anemia serum to provide final concentrations of $200 ; 600$, and 1,000 pg per $\mathrm{ml}$, respectively. In two separate experiments it is shown that with the same total amount of $\mathrm{B}_{12}{ }^{67} \mathrm{Co}$, uptake was greatest when the saturation of the serum $B_{12}$ binding proteins was greatest. The highest point on each curve was obtained with $1 \mathrm{ml}$ of serum containing the stated amount of added $\mathrm{B}_{12}{ }^{\mathrm{57}} \mathrm{Co}$; lower points used such fractions of $1 \mathrm{ml}$ as to provide the quantities of $\mathrm{B}_{12-}{ }^{87} \mathrm{Co}$ indicated on the abscissa. transferred most efficiently from serum protein with the greatest $\mathrm{B}_{12}{ }^{-57}$ Co saturation, even when the total amount of $\mathrm{B}_{12}{ }^{-57} \mathrm{Co}$ available to the erythrocytes in the test system is equal. If the quantity of transcorrin molecules is assumed to exceed the number of reticulocyte receptor sites available, this finding would imply that the reticulocyte may not take up the $\mathrm{B}_{12}$-transcorrin (23) complex in marked preference to transcorrin alone from a mixture of both free and complexed carrier. Preferential uptake of $\mathrm{B}_{12}{ }^{-57} \mathrm{Co}$-transcorrin over transcorrin alone would be expected to yield similar uptake of $\mathrm{B}_{12}{ }^{-57} \mathrm{Co}$ from $1 \mathrm{ml}$ of serum to which was added $200 \mathrm{pg}$ of $\mathrm{B}_{12}{ }^{-57} \mathrm{Co}$ as from $\frac{1}{3} \mathrm{ml}$ of the same serum containing $200 \mathrm{pg}$ of $\mathrm{B}_{12^{-}}{ }^{57} \mathrm{Co}$ (when in both instances transcorrin is not saturated with $\mathrm{B}_{12^{-57}} \mathrm{Co}$ ).

\section{Cellular factors}

Metabolic inhibitors. The effect of metabolic inhibitors on $\mathrm{B}_{12}{ }^{-57}$ Co uptake by erythrocytes was investigated by adding $0.5 \mathrm{ml} 10^{-2} \mathrm{M}$ sodium cyanide $(\mathrm{NaCN}), 10^{-2} \mathrm{M}$ sodium fluoride $(\mathrm{NaF})$, and $10^{-2} \mathrm{M}$ sodium arsenate $\left(\mathrm{Na}_{2} \mathrm{HAsO}_{4}\right)$ to the standard incubation mixtures. No significant decreases in $\mathrm{B}_{12}$ uptake could be demonstrated ( $\mathrm{Ta}$ ble II). When test cells were preincubated with $10^{-2} \mathrm{M} \mathrm{NaCN}$ for 15 minutes at $37^{\circ} \mathrm{C}$ before addition of serum-bound $\mathrm{B}_{12^{-}}{ }^{37} \mathrm{Co}$, similar results were obtained.

Digitalis glycosides. The active transfer of sodium and potassium ions across red cell membranes is inhibited by digitalis glycosides (24); this may be due to inhibition of cellular ATPase and the "sodium pump" (25). Five-tenths ml deslanoside (Cedilanid-D, $2 \times 10^{-4} \mathrm{M}$ concentration) had no effect on $\mathrm{B}_{12}{ }^{-57} \mathrm{Co}$ uptake (Table II).

TABLE II

Effect of metabolic inhibitors on $B_{12^{-57}}$ Co uptake by erythrocytes from serum

\begin{tabular}{lc}
\hline \multicolumn{1}{c}{$\begin{array}{c}\text { Agent }(0.5 \mathrm{ml}) \text { added } \\
\text { to } 0.5 \mathrm{ml} \text { serum }\end{array}$} & $\begin{array}{c}\text { B12-57Co up- } \\
\text { take by } 1 \mathrm{ml} \\
\text { erythrocytes as } \\
\text { \% of uptake } \\
\text { from control* }\end{array}$ \\
\hline $0.85 \% \mathrm{NaCl}^{*}(\mathrm{Control})$ & 100 \\
$\mathrm{NaCN}\left(10^{-2} \mathrm{M}\right)$ & $95.9 \pm 4.1$ \\
$\mathrm{NaF}\left(10^{-2} \mathrm{M}\right)$ & $113.9 \pm 5.7$ \\
$\mathrm{NaHAsO}\left(10^{-2} \mathrm{M}\right)$ & $112.2 \pm 6.9$ \\
Deslanoside $\left(2 \times 10^{-4} \mathrm{M}\right)$ & $97.3 \pm 4.8$
\end{tabular}

* Mean of five estimations \pm standard error. 
$B_{12}{ }^{-57}$ Co uptake by stored cells. A portion of reticulocyte-rich blood thrice washed with $\mathrm{CaCl}_{2}$ $\mathrm{NaCl}$ and then suspended in this solution was refrigerated at $4^{\circ} \mathrm{C}$ for periods up to 4 days. Ability to adsorb $\mathrm{B}_{12}{ }^{-57}$ Co was then assessed and compared with the original uptake. A gradual loss of $\mathrm{B}_{12}$ uptake was evident, but erythrocytes stored for 4 days could still adsorb $58 \%$ of the original uptake. Over the same period the reticulocyte count dropped from $13 \%$ to $7.6 \%$.

Cellular membrane changes. a) Enzyme treatment. Powdered trypsin ${ }^{2}$ and papain ${ }^{3}$ were dissolved in physiological saline in concentrations of $0.1,0.01$, and $0.001 \%$. Thrice washed reticulocyte-rich red cell suspensions were incubated at $37^{\circ} \mathrm{C}$ for 1 hour with volumes of these enzyme solutions equal to the volume of red cells present. After two additional washings, $\mathrm{B}_{12}{ }^{-57} \mathrm{Co}$ uptake by red cells was determined and compared with uptake by control red cells incubated with saline instead of enzyme.

Results (Table III) indicate that $0.1 \%$ enzyme greatly reduced $\mathrm{B}_{12}{ }^{-57} \mathrm{Co}$ uptake; even at $0.001 \%$

\footnotetext{
${ }^{2}$ Standardized trypsin, 1:250, control no. 408327, Difco Laboratories, Detroit, Mich.

${ }^{3}$ Papain, N. F., viii, control no. 476295, Difco Laboratories.
}

TABLE III

Effect of alterations in the reticulocyte membrane on $B_{12^{-57}}$ Co uptake by erythrocytes from serum

\begin{tabular}{lc}
\hline \hline \multicolumn{1}{c}{$\begin{array}{c}\text { Agent }(0.5 \mathrm{ml}) \text { preincubated } \\
\text { with erythrocytes }\end{array}$} & $\begin{array}{c}\text { B12-57Co up- } \\
\text { take by 1 ml } \\
\text { erythrocytes as } \\
\% \text { of uptake } \\
\text { from control* }\end{array}$ \\
\hline $\mathrm{NaCl}(0.85 \%)$ (Control) & 100 \\
Trypsin $(0.1 \%)$ & $11.6 \pm 1.5$ \\
Trypsin $(0.001 \%)$ & $47.8 \pm 4.3$ \\
Papain $(0.1 \%)$ & $14.2 \pm 2.1$ \\
Papain $(0.01 \%)$ & $45.0 \pm 10.9$ \\
Papain (0.001\%) & $83.4 \pm 10.1$ \\
Anti-D coated erythrocytes & $97.8 \pm 2.4$
\end{tabular}

* Mean of five estimations \pm standard error.

concentration, uptake was appreciably decreased by trypsin. Enzyme treatment did not cause visible hemolysis of erythrocytes.

b) Coating of cell surface with antibody. Reticulocyte-rich red cells were collected from a patient with blood group $\mathrm{A}, \mathrm{Rh}$ positive ( $\mathrm{CDe}$ ), and incubated at $37^{\circ} \mathrm{C}$ for 1 hour with high titer anti-D antiserum in volumes equal to the volume of the test erythrocytes. This procedure coats the individual red cell with approximately 24,000 antibody molecules (26) but causes no macroscopic erythrocyte agglutination. Coated cells were twice washed with $\mathrm{CaCl}_{2}-\mathrm{NaCl}$ and then tested

TABLE IV

Elution of $B_{12-57}$ Co from erythrocytes after uptake from serum and saline

\begin{tabular}{|c|c|c|c|}
\hline & Uptake medium & Elution medium & $\begin{array}{l}\text { B12-57Co on } 1 \mathrm{ml} \\
\text { erythrocytes, as \% } \\
\text { of pre-elution } \\
\text { radioactivity }\end{array}$ \\
\hline & $\begin{array}{l}\text { Serum } \\
\text { Serum } \\
\text { Serum } \\
\text { Serum } \\
\text { Serum } \\
\text { Serum } \\
\text { Serum } \\
\text { Serum }\end{array}$ & $\begin{array}{l}\text { None } \\
\mathrm{Na} \text { EDTA }\left(10^{-1} \mathrm{M}, 0.5 \mathrm{ml}\right) \\
\mathrm{NaCl}(0.9 \%, 0.5 \mathrm{ml}) \\
\text { Normal serum }(0.5 \mathrm{ml}) \\
\mathrm{B}_{12} \text {-deficient serum }(0.5 \mathrm{ml}) \\
\text { Chronic myelogenous leukemia serum }(0.5 \mathrm{ml}) \\
\text { Trypsin }(0.1 \%, 1.0 \mathrm{ml}) \\
\text { Trypsin }(0.001 \%, 1.0 \mathrm{ml})\end{array}$ & $\begin{array}{l}100 \\
12.5 \pm 2.0 \\
36.3 \pm 3.7 \\
49.6 \pm 4.7 \\
48.9 \pm 3.0 \\
49.5 \pm 6.1 \\
0.62,9.91 \ddagger \\
9.4 \pm 1.4\end{array}$ \\
\hline 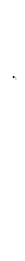 & $\begin{aligned} & \\
& \text { 1) } \text { Serum } \\
& \text { Serum } \\
& \text { Saline } \\
& \text { Saline } \\
& \text { 2) } \begin{array}{l}\text { Serum } \\
\text { Serum } \\
\text { Saline } \\
\text { Saline }\end{array}\end{aligned}$ & $\begin{array}{l}\text { None } \\
\mathrm{Na}_{2} \text { EDTA } \\
\text { None } \\
\mathrm{Na}_{2} \text { EDTA } \\
\mathrm{None} \\
\mathrm{Na}_{2} \text { EDTA } \\
\mathrm{None}^{\mathrm{Na}} \text { EDTA }\end{array}$ & $\begin{array}{ll}100 & \\
47.5, & 21.6 \ddagger \\
100 & \\
101.3, & 97.8 \ddagger \\
100 & \\
25.4, & 21.1 \ddagger \\
100 & \\
120.1, & 116.9 \ddagger\end{array}$ \\
\hline
\end{tabular}

* After $\mathrm{B}_{12^{-}}{ }^{57} \mathrm{Co}$ transfer (incubation for 60 minutes at $37^{\circ} \mathrm{C}$ ), cells were twice washed and reincubated with elution media ( 30 minutes at $37^{\circ} \mathrm{C}$ ); $\mathrm{B}_{12^{-57}} \mathrm{Co}$ remaining on erythrocytes was compared with pre-elution radioactivity.

$\dagger$ After $\mathrm{B}_{12^{-5}}{ }^{57} \mathrm{Co}$ uptake during 1) 30-minute or 2) 2-hour incubation periods, cells were incubated for 30 minutes at $37^{\circ} \mathrm{C}$, with $\mathrm{Na}_{2}$ EDTA $\left(10^{-1} \mathrm{M}, 0.5 \mathrm{ml}\right)$, without prior washing. Residual $\mathrm{B}_{12^{-5}}{ }^{5} \mathrm{Co}$ on erythrocytes was compared with pre-elution controls.

$\ddagger$ Only two estimations performed; other values are means \pm standard errors of five samples. 
TABLE V

Toluene separation of erythrocyte stroma and hemolysate, after uptake of $B_{12^{-57}}$ Co from serum or saline

\begin{tabular}{|c|c|c|c|c|c|}
\hline \multirow[b]{2}{*}{ Experiment } & \multirow{2}{*}{$\begin{array}{c}\text { Incubation } \\
\text { time* }\end{array}$} & \multirow{2}{*}{$\begin{array}{l}\text { Uptake } \\
\text { medium }\end{array}$} & \multicolumn{3}{|c|}{$\mathrm{B}_{12^{-67} \mathrm{Co}}$ on $1 \mathrm{ml}$ erythrocytes } \\
\hline & & & Total & Stroma & Hemolysate \\
\hline & & & $p g$ & $p g \quad \%$ & $p g \quad \%$ \\
\hline \multirow[t]{2}{*}{1} & 30 minutes & Serum & 24.4 & $18.7(76.6)$ & $5.7(23.4)$ \\
\hline & 30 minutes & Saline & 11.7 & $6.2(53.0)$ & $5.5(47.0)$ \\
\hline 2 & 60 minutes & Serum & 21.2 & $15.0(71.7)$ & $6.2(28.3)$ \\
\hline \multirow[t]{2}{*}{3} & 3 hours & Serum & 18.5 & $15.0(81.1)$ & $3.5(18.9)$ \\
\hline & 3 hours & Saline & 6.4 & $3.3(51.6)$ & $3.1(48.4)$ \\
\hline
\end{tabular}

* Initial incubation at $37^{\circ} \mathrm{C}$ : uptake of $\mathrm{B}_{12-57} \mathrm{Co}$ by erythrocytes from serum and saline media.

for their ability to take up $\mathrm{B}_{12}{ }^{-57} \mathrm{Co}$; results were then compared with uptake by control reticulocytes incubated with saline instead of antiserum. Precoating with $\mathrm{Rh}$ antibody did not decrease $\mathrm{B}_{12}{ }^{-{ }^{57} \mathrm{Co}}$ uptake by reticulocytes (Table III).

Elution of $B_{12}{ }^{-57}$ Co from test reticulocytes. a) Elution of $B_{12}{ }^{-57}$ Co from erythrocytes after serum transfer. The labeled cells were twice washed with $\mathrm{CaCl}_{2}-\mathrm{NaCl}$ and reincubated for 30 minutes at $37^{\circ} \mathrm{C}$ with various elution media, in volumes comparable to those used in the standard transfer procedure. Remaining cellular radioactivity was determined after three $\mathrm{CaCl}_{2}-\mathrm{NaCl}$ washes and compared with a pre-elution radioactivity. Elution was maximal with $10^{-1} \mathrm{M} \mathrm{Na}_{2}$ EDTA and trypsin, less marked with serum and saline. Normal, chronic myelogenous leukemia, and $\mathrm{B}_{12}$-deficient serum eluted equal amounts of $\mathrm{B}_{12}{ }^{-57} \mathrm{Co}$ (Table IV).

b) Comparison of elution of $B_{12}{ }^{-57} \mathrm{Co}$ from erythrocytes after saline transfer to that after serum transfer. One-half $\mathrm{ml}^{10^{-1}} \mathrm{M} \mathrm{Na}_{2}$ EDTA was added to standard test suspensions after red cells had been incubated with $\mathrm{B}_{12}{ }^{-57} \mathrm{Co}$ in saline and serum for 30 minutes and 2 hours. Further incubation of 30 minutes was allowed; the cells were then thrice washed, and remaining radioactivity of the erythrocytes was determined. Results were compared with cellular $\mathrm{B}_{12}{ }^{57} \mathrm{Co}$ immediately before $\mathrm{Na}_{2}$ EDTA addition (Table IV). Whereas $\mathrm{Na}_{2}$ EDTA caused elution of $\mathrm{B}_{12}{ }^{-57} \mathrm{Co}$ from erythrocytes when transferred by serum proteins, $\mathrm{B}_{12^{-}}{ }^{57} \mathrm{Co}$ taken up from saline medium was not eluted.

Site of $B_{12}{ }^{-57} \mathrm{Co}$ attachment. Reticulocyte-rich erythrocytes containing $\mathrm{B}_{12}{ }^{-57} \mathrm{Co}$ taken up from serum and saline media were twice washed with
$\mathrm{CaCl}_{2}-\mathrm{NaCl}$ and then hemolyzed in 4 vol distilled water. Toluene, $2 \mathrm{ml}$, was added; the specimens were shaken intermittently for 5 minutes and then centrifuged at $3,000 \mathrm{rpm}$ for 15 minutes. The red cell stroma was now tightly packed on the under surface of the toluene layer; the hemolysate could be separated from the stroma by gently passing a thin glass pipette down the side of the tube. The radioactivity of the two fractions was determined (Table V).

More than $70 \%$ of $\mathrm{B}_{12}{ }^{-{ }^{57}} \mathrm{Co}$ transferred to red cells by serum was present in the stromal layer. Activity in the hemolysate was not significantly greater after 3 hours of incubation than after 30 minutes, suggesting insignificant penetration of $\mathrm{B}_{12}{ }^{-{ }^{57}} \mathrm{Co}$ into the red cell even with prolonged incubation. The percentage saline-transferred $\mathrm{B}_{12}{ }^{-57} \mathrm{Co}$ in hemolysate and stroma was similar in the 30-minute and 3-hour specimens.

\section{Discussion}

This study suggests that serum-mediated $B_{12}-$ ${ }^{57} \mathrm{Co}$ uptake by the reticulocyte-rich erythrocyte suspension is essentially a calcium $\left(\mathrm{Ca}^{++}\right)$- or magnesium $\left(\mathrm{Mg}^{++}\right)$-dependent surface adsorption phenomenon or both. The EDTA studies suggest that strontium $\left(\mathrm{Sr}^{++}\right)$may partially replace these cations. Similar findings were reported for $\mathrm{B}_{12}$ uptake by the liver and intestinal systems $(10,27)$. When the $\mathrm{B}_{12}{ }^{-57}$ Co-labeled test cells were incubated with various elution media, most of the $\mathrm{B}_{12}{ }^{-57} \mathrm{Co}$ could be eluted by trypsin and $\mathrm{Na}_{2}$ EDTA (Table IV). $\mathrm{Na}_{2}$ EDTA elution may be due to chelation of essential $\mathrm{Ca}^{++}$bonds. Reincubation with serum also caused $\mathrm{B}_{12}{ }^{-57} \mathrm{Co}$ elution; no difference was found between normal, chronic myelogenous leukemia, and $\mathrm{B}_{12}$-deficient serum. Herbert (10) similarly found $\mathrm{Na}_{2}$ EDTA to cause marked elution of $\mathrm{B}_{12}{ }^{-{ }^{60}} \mathrm{Co}$ from rat liver slices, whereas Jandl, Inman, Simmons, and Allen (28) could demonstrate significant elution of transferrin-facilitated ${ }^{59} \mathrm{Fe}$ uptake only when reticulocyte-poor suspensions were used. Trypsin, even in $0.001 \%$ concentrations, caused elution of $90.6 \%$ of the initial $\mathrm{B}_{12}{ }^{-57} \mathrm{Co}$ taken up by reticulocytes. With toluene separation of red cell stroma and hemolysate, more than $70 \%$ of serum-transferred $\mathrm{B}_{12}{ }^{-57} \mathrm{Co}$ was located in the stroma (Table V); radioactivity in the hemolysate was no greater after 3 hours of incubation than after 30 minutes. 
The evidence thus suggests that $\mathrm{B}_{12}{ }^{-57} \mathrm{Co}$ transferred by serum penetrates the red cell membrane only poorly.

Metabolic poisons such as $\mathrm{NaCN}$ and $\mathrm{Na}_{2} \mathrm{H}-$ $\mathrm{AsO}_{4}$ and an inhibitor of glycolysis, $\mathrm{NaF}$ (29), did not decrease $\mathrm{B}_{12}{ }^{-57} \mathrm{Co}$ uptake (Table II), indicating that active cellular metabolism is of little importance in the phenomenon under study. Jandl and co-workers (28) reported a pronounced decrease of ${ }^{50} \mathrm{Fe}$ uptake by reticulocytes in the presence of these materials. However, in their system, ${ }^{59} \mathrm{Fe}$ was actually transported into the cell. Laurell and Morgan (30) found these substances to inhibit in vitro ${ }^{59} \mathrm{Fe}$ uptake by rat placenta, and other workers similarly described decreased $\mathrm{B}_{12^{-}}$ ${ }^{57}$ Co uptake by Ehrlich ascites tumor cells (13) and decreased glycine uptake by reticulocytes (31). Herbert (10), on the other hand, found 2,4-dinitrophenol ineffective in reducing $\mathrm{B}_{12}{ }^{-60} \mathrm{Co}$ uptake by rat liver slices and concluded that this is a surface adsorption phenomenon. Trypsin and papain, enzymes known to damage the surface membrane, greatly decreased $\mathrm{B}_{12}{ }^{-57} \mathrm{Co}$ uptake in the present study (Table III). Jandl and associates (28) and Jandl and Katz (32) found similar results with ${ }^{59} \mathrm{Fe}$ uptake by reticulocytes. They also reported that ${ }^{59} \mathrm{Fe}$ uptake is impaired when cells are precoated with antibody (28); we were unable to show decreased $\mathrm{B}_{12}{ }^{-57} \mathrm{Co}$ uptake by erythrocytes coated with anti-D antibody (Table III). $\quad B_{12}{ }^{-57}$ Co uptake from saline in the absence of serum showed very different characteristics. It was not reticulocyte dependent, was not affected by $\mathrm{Ca}^{++}$chelating agents, was quantitatively less than serum transfer, and $\mathrm{Na}_{2}$ EDTA did not elute "saline-transferred" $\mathrm{B}_{12}{ }^{-{ }^{57}} \mathrm{Co}$ from the cell surface. Although uptake from serum increased with a rising reticulcyte count, it is probable that mature erythrocytes also take up significant amounts of $\mathrm{B}_{12}$. [Extrapolation of the "uptake slopes" in Figure 1 shows that the ordinate $(0 \%$ reticulocyte count) is invariably reached much above the zero uptake level.]

The present findings suggest that the mechanism of serum-mediated vitamin $B_{12}$ uptake by the reticulocyte-rich red cell suspension is very similar to that for intrinsic factor-mediated vitamin $B_{12}$ uptake by intestinal mucosa (33). Because serum was preincubated with subsaturating doses of $\mathrm{B}_{12^{-57}} \mathrm{Co}$, no unbound radioactive $\mathrm{B}_{12}$

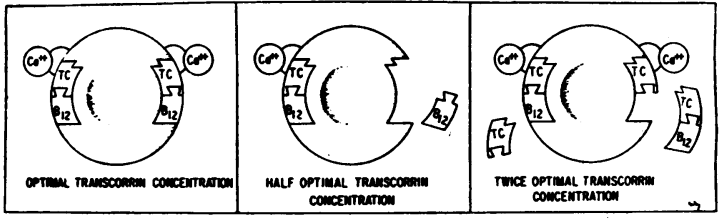

Fig. 6. Schematic REPRESENTAtion of the SUgGeSted MECHANISM OF CALCIUM-DEPENDENT BINDING OF $B_{12-}$ TRANSCORRIN (TC) COMPLEXES TO RETICULOCYTE RECEPTORS.

was present in those experiments testing serum transfer of $B_{12}$. The red cell surface probably contains receptor sites adapted to receive the transport protein $\mathrm{B}_{12}$ complex but may also accept the transport protein per se, depending on amount and saturation of carrier protein by $B_{12}$. In spite of equal absolute amounts of $\mathrm{B}_{12}{ }^{-57} \mathrm{Co}$, most radioactive $B_{12}$ was transferred by the serum with highest $\mathrm{B}_{12}{ }^{-{ }^{57}} \mathrm{Co}$ concentration (Figure 5). Ionic calcium probably consolidates the carrier protein bond to the reticulocyte surface (Figure 6). Vitamin $B_{12}$ uptake in the absence of plasma protein may represent simple diffusion. In the present study $\mathrm{B}_{12}$ transferred by protein entered the test cells in minute amounts at the most. One could speculate that the developing erythropoietic cell probably loses its ability to incorporate $B_{12}$ as its declining metabolic activity decreases the need for this coenzyme. At the reticulocyte stage, and even with mature erythrocytes, active $B_{12}$ receptor sites may still be present on the cell surface, but the cell no longer needs $B_{12}$, and the vitamin is not transferred from the surface to the interior of the cell. The work of Schilling and Meyer (34), who showed that tracer doses of radioactive $B_{12}$ are incorporated into erythroid cells only at the nucleated precursor stage, conforms with this hypothesis. They found that radioactivity incorporated in this manner is located in the hemolysate rather than stroma and that it progressively disappears from the cell during

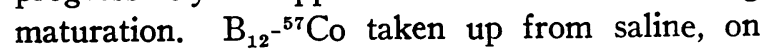
the other hand, probably penetrates the cell membrane independent of receptor sites. Our in vitro experimental model thus suggests a dual mechanism for $B_{12}$ transport to erythrocytes, as exists for transport across the small intestine: a glycoprotein-mediated transport operative primarily in the presence of physiologic quantities of the vitamin, and diffusion operative primarily in the 
presence of supraphysiologic quantities of the vitamin. The rapid rate of serum-mediated $\mathrm{B}_{12^{-}}$ ${ }^{57}$ Co transfer resembles the "primary" phase of the biphasic $B_{12}$ uptake curve found with mouse ascites tumor cells (12). However, we could not demonstrate a "secondary" uptake. With saline transfer the initial rapid uptake may have been facilitated by minute amounts of contaminating serum protein.

A number of workers have studied ${ }^{59} \mathrm{Fe}$ uptake by reticulocytes $(28,35-37)$. The most recent evidence suggests that the absolute amount of iron present is the critical factor (35-37). In vivo tissue uptake of iron, on the other hand, seems to correlate better with transferrin saturation than with serum iron, per se (38). The present study suggests that the reticulocyte discriminates imperfectly between $\mathrm{B}_{12}$-carrying transcorrin and transcorrin alone, since $\mathrm{B}_{12}{ }^{-57} \mathrm{Co}$ uptake by reticulocytes was related to the number of $\mathrm{B}_{12}{ }^{-57} \mathrm{Co}-$ transcorrin molecules in relation to the number of transcorrin molecules not carrying $\mathrm{B}_{12}{ }^{-57} \mathrm{Co}$ (Figure 5). However, this problem can only be finally solved by labeling the carrier protein and $B_{12}$ separately in the same experiment. Adding various amounts of $\mathrm{B}_{12^{-57}} \mathrm{Co}$ to pernicious anemia plasma may sequentially saturate different binding proteins with subsequent changes in transferring properties. A method for rapid separation of $\mathrm{B}_{12^{-}}$ binding $\alpha$ from $\beta$-globulin is presented elsewhere (39) as is evidence that the $\beta B_{12}$ binder delivers more $B_{12}$ to reticulocytes than does the $\alpha$ binder (40).

\section{Summary}

1. Serum-mediated $\mathrm{B}_{12^{-}}{ }^{57}$ Co uptake by reticulocyte-rich erythrocytes appeared to represent rapid adsorption to the red cell surface; ionic calcium or magnesium was essential for this reaction, but strontium could partially replace these cations.

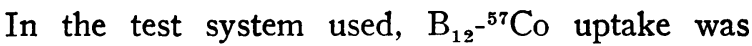
maximal after 20 minutes' incubation, with near maximal adsorption during the first 5 minutes. Uptake increased with a rising reticulocyte count, but mature erythrocytes could also adsorb small amounts of $\mathrm{B}_{12}{ }^{-57} \mathrm{Co}$. Trypsin and papain reduced $\mathrm{B}_{12}$ uptake, but metabolic poisons had no effect. $\mathrm{Na}_{2}$ EDTA and trypsin could elute virtually all $\mathrm{B}_{12}{ }^{-{ }^{57}} \mathrm{Co}$ previously adsorbed to erythro- cytes; elution was much less complete with serum and saline.

2. $B_{12^{-}}{ }^{57}$ Co taken up from a saline medium was less than from serum, did not concentrate in red cell stroma (unlike $\mathrm{B}_{12}{ }^{-57}$ Co from serum), did not show calcium or reticulocyte dependence, and could not be eluted by $\mathrm{Na}_{2}$ EDTA.

3. We suggest that two mechanisms exist for $B_{12}$ uptake by erythrocytes analogous to the dual mechanisms for $B_{12}$ transport across the intestinal mucosa : a) calcium- or magnesium- (or both) dependent, carrier glycoprotein-mediated transfer to receptors on the cell surface, operative primarily in the presence of physiologic quantities of $B_{12}$ and $b$ ) simple diffusion independent of receptor sites (primarily operative in the presence of excess unbound $\mathrm{B}_{12}$ ).

\section{Acknowledgments}

We wish to thank Mr. John Farrelly and Misses Le Teng Go and Melody Lee for technical assistance.

\section{References}

1. Retief, F. P., C. W. Gottlieb, and V. Herbert. Studies of transfer of protein-bound $\mathrm{Co}^{5 \pi} \mathrm{B}_{12}$ from human serum to reticulocytes: calcium-dependence; decreased transfer from chronic myelogenous leukemia (CML) serum (abstract). Blood 1965, 26, 869.

2. Pitney, W. R., M. F. Beard, and E. J. van Loon. Observations on the bound form of vitamin $B_{12}$ in human serum. J. biol. Chem. 1954, 207, 143.

3. Ostrowski, W., B. Skarzynski, and Z. Zak. Vitamin $B_{12}$ in the protein fractions of human blood serum. Bull. Acad. pol. Sci. Cl. 2 1954, $2,9$.

4. Miller, A. The in vitro binding of cobalt ${ }^{\circ 0}$ labeled vitamin $\mathrm{B}_{12}$ by normal and leukemic sera. J. clin. Invest. 1958, 37, 556.

5. Hall, C. A., and A. E. Finkler. In vivo plasma vitamin $B_{12}$ binding in $B_{12}$ deficient and nondeficient subjects. J. Lab. clin. Med. 1962, 60, 765.

6. Miller, A., and J. F. Sullivan. Electrophoretic studies of the vitamin $\mathrm{B}_{12}$-binding protein of normal and chronic myelogenous leukemia serum. J. clin. Invest. 1959, 38, 2135.

7. Weinstein, I. B., S. M. Weissman, and D. M. Watkin. The plasma vitamin $B_{12}$ binding substance: I. Its detection in the seromucoid fraction of plasma from normal subjects and patients with chronic myelocytic leukemia. J. clin. Invest. 1959, 38, 1904.

8. Callender, S. T., and L. G. Lajtha. On the nature of Castle's hemopoietic factor. Blood 1951, 6, 1234. 
9. Miller, O. N., J. L. Raney, and F. M. Hunter. Effect of intrinsic factor on uptake of radioactive vitamin $B_{12}$ by slices of rat liver. Fed. Proc. 1957, 16, 393.

10. Herbert, V. Studies of the mechanism of the effect of hog intrinsic factor concentrate on the uptake of vitamin $\mathrm{B}_{12}$ by rat liver slices. J. clin. Invest. 1958, 37, 646.

11. Herbert, V. Studies on the role of intrinsic factor in vitamin $B_{12}$ absorption, transport, and storage. Amer. J. clin. Nutr. 1959, 7, 433.

12. Cooper, B. A., and W. Paranchych. Selective uptake of specifically bound cobalt-58 vitamin $B_{12}$ by human and mouse tumour cells. Nature (Lond.) 1961, 191, 393.

13. Paranchych, W., and B. A. Cooper. Factors influencing the uptake of cyanocobalamin (vitamin $B_{12}$ ) by Ehrlich ascites carcinoma cells. Biochim. biophys. Acta (Amst.) 1962, 60, 393.

14. Finkler, A. E., C. A. Hall, and J. V. Landau. Uptake by $\mathrm{He}-\mathrm{La}$ cells of normal and abnormal $\mathrm{B}_{12}$ binding proteins. Fed. Proc. 1965, 24, 679.

15. Hall, C. A., and A. E. Finkler. The dynamics of transcobalamin II. A vitamin $\mathrm{B}_{12}$ binding substance in plasma. J. Lab. clin. Med. 1965, 65, 459.

16. Herbert, V. Plasma vitamin $B_{12}$ binding protein (abstract). Ann. intern. Med. 1963, 58, 730.

17. Herbert, V., and L. W. Sullivan. Activity of coenzyme $\mathrm{B}_{12}$ in man. Ann. N. Y. Acad. Sci. 1964, $112,855$.

18. Bertcher, R. W., L. M. Meyer, and M. Schneider. Characteristics of vitamin $B_{12}$ binding by erythrocytes and their components. Acta haemat. (Basal) 1962, 27, 354.

19. Meyer, L. M. Studies on serum binding of vitamin $\mathrm{B}_{12}$ mechanisms and clinical implications. Ser. haemat. 1965, 3, 91.

20. Lau, K.-S., C. Gottlieb, L. R. Wasserman, and V. Herbert. Measurement of serum vitamin $B_{12}$ level using radioisotope dilution and coated charcoal. Blood 1965, 26, 202.

21. Gottlieb, C., K.-S. Lau, L. R. Wasserman, and V. Herbert. Rapid charcoal assay for intrinsic factor (IF), gastric juice unsaturated $B_{12}$ binding capacity, antibody to $I F$, and serum unsaturated $B_{12}$ binding capacity. Blood 1965, 25, 875 .

22. Prankerd, T. A. J. The aging of red cells. J. Physiol. (Lond.) 1958, 143, 325.

23. Herbert, V. Drugs effective in megaloblastic anemias in The Pharmacological Basis of Therapeutics, 3rd ed., L. S. Goodman and A. Gilman, Eds. New York, Macmillan, 1965, p. 1420.

24. Schatzmann, H. M. Herzglykoside als Hemmostoffe für den aktiven Kalium-und Natriumtransport durch die Erythrocytenmembran. Helv. physiol. pharmacol. Acta 1953, 11, 346.
25. Moe, G. K., and A. E. Farah. Digitalis and allied cardiac glycosides in The Pharmacological Basis of Therapeutics, 3rd ed., L. S. Goodman and A. Gilman, Eds. New York, Macmillan, 1965, p. 679.

26. Hughes-Jones, N. C., B. Gardner, and R. Telford. Studies on the reaction between blood-group antibody anti-D and erythrocytes. Biochem. J. 1963. 88, 435.

27. Herbert, V., and W. B. Castle. Divalent cation and $\mathrm{pH}$ dependence of rat intrinsic factor action in everted sacs and mucosal homogenates of rat small intestine. J. clin. Invest. 1961, 40, 1978.

28. Jandl, J. H., J. K. Inman, R. L. Simmons, and D. W. Allen. Transfer of iron from serum iron-binding protein to human reticulocytes. J. clin. Invest. 1959, 38, 161.

29. Harris, J. W. The Red Cell. Cambridge, Harvard University Press, 1963, p. 216.

30. Laurell, C.-B., and E. Morgan. Iron exchange between transferrin and the placenta in the rat. Acta physiol. scand. 1964, 62, 271.

31. Riggs, T. R., H. N. Christensen, and I. M. Palatine. Concentrating activity of reticulocytes for glycine. J. biol. Chem. 1952, 194, 53.

32. Jandl, J. H., and J. H. Katz. The plasma-to-cell cycle of transferrin. J. clin. Invest. 1963, 42, 314.

33. Herbert, V., R. R. Streiff, and L. W. Sullivan. Notes on vitamin $\mathrm{B}_{12}$ absorption; autoimmunity and childhood pernicious anemia; relation of intrinsic factor to blood group substance. Medicine (Baltimore) $1964,43,679$.

34. Schilling, R. F., and O. O. Meyer. Incorporation of vitamin $\mathrm{B}_{12}$ into immature erythrocytes. Trans. Ass. Amer. Phycns 1964, 77, 79.

35. Schade, A. L. Iron uptake by erythropoietic and other tissues from native serum siderophilin and from isolated purified siderophilin. Farmaco, Ed. sci. 1964, 19, 185.

36. Morgan, E. H., and C.-B. Laurell. Studies on the exchange of iron between transferrin and reticulocytes. Brit. J. Haemat. 1963, 9, 471.

37. Katz, J. H. The delivery of iron to the immature red cell: a critical review. Ser. haemat. 1965, 6, 15.

38. Bainton, D. F., and C. A. Finch. The diagnosis of iron deficiency anemia. Amer. J. Med. 1964, 37, 62.

39. Retief, F. P., C. W. Gottlieb, S. Kochwa, P. Pratt, and V. Herbert. Separation of vitamin $B_{12}$-binding proteins of serum, gastric juice and saliva by rapid DEAE cellulose chromatography. Blood 1967 , in press.

40. Retief, F. P., C. W. Gottlieb, and V. Herbert. Delivery of $\mathrm{Co}^{57} \mathrm{~B}_{12}$ to erythrocytes from alpha and beta globulin of normal, $\mathrm{B}_{12}$-deficient, and chronic myeloid leukemia serum. Blood 1967, in press. 